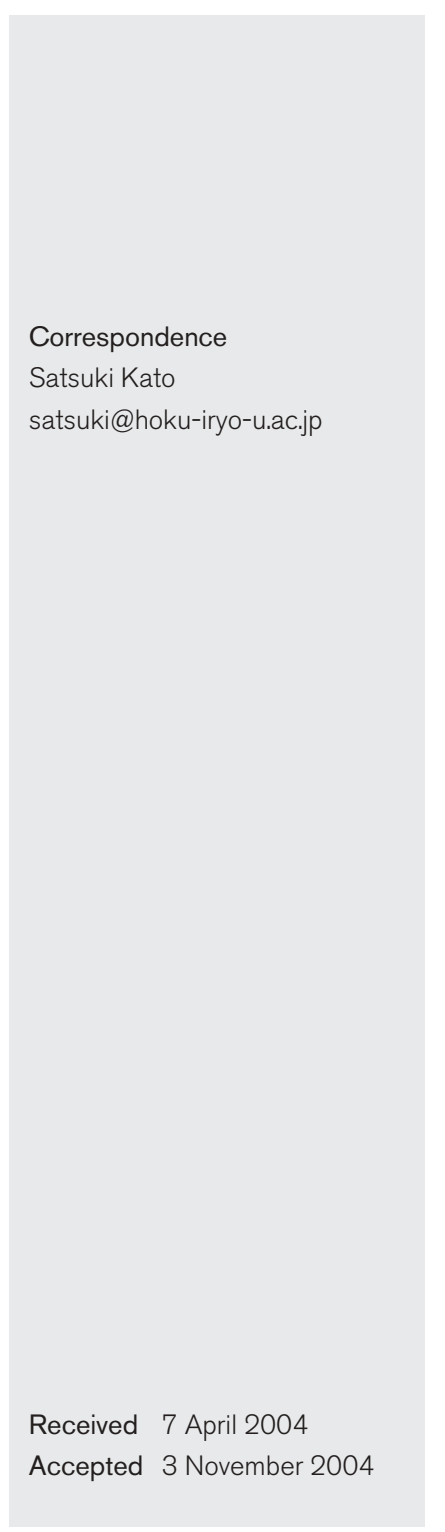

\title{
Actinobacillus actinomycetemcomitans induces apoptosis in human monocytic THP-1 cells
}

\author{
Satsuki Kato, ${ }^{1}$ Norihiko Sugimura, ${ }^{1}$ Keisuke Nakashima, ${ }^{1}$ Tatsuji Nishihara ${ }^{2}$ \\ and Yusuke Kowashi ${ }^{1}$ \\ ${ }^{1}$ Department of Periodontology and Endodontology, School of Dentistry, Health Sciences University \\ of Hokkaido, 1757 Kanazawa, Ishikari-Tobetsu, Hokkaido 061-0293, Japan \\ ${ }^{2}$ Department of Oral Microbiology, Kyusyu Dental College, Fukuoka 803-8580, Japan
}

\begin{abstract}
It has previously been reported that the murine macrophage cell line J774.1 and the human oral epithelial cell line KB undergo apoptosis as a result of Actinobacillus actinomycetemcomitans infection. Recent studies have demonstrated that apoptosis regulation is modulated by multiple phosphorylation of several different protein kinases, including the major subtypes of the mitogenactivated protein kinase (MAPK) family. The MAPK family promotes cell survival and/or proliferation in response to growth factor stimulation, or apoptosis in response to various stress stimuli. The primary objective of the present investigation was to clarify whether human immune cells undergo apoptosis following $A$. actinomycetemcomitans infection and, if so, to establish the involvement of the MAPK family. Human monocytic THP-1 cells were infected with A. actinomycetemcomitans in microtubes. Lactate dehydrogenase release into the culture supernatant and DNA fragmentation in the cells were monitored. DNA fragmentation was also identified by agarose gel electrophoresis. Cell death following $A$. actinomycetemcomitans infection occurred by apoptosis, shown by an increase in the proportion of fragmented DNA and the typical ladder pattern of DNA fragmentation indicative of apoptosis. Furthermore, p38 MAPK activity and tumour necrosis factor alpha (TNF- $\alpha$ ) levels increased following $A$. actinomycetemcomitans infection. In contrast, cell death and TNF- $\alpha$ levels in infected cells decreased upon addition of a p38 inhibitor or an anti-TNF- $\alpha$ antibody. However, exogenous TNF- $\alpha$ could not induce apoptosis in uninfected THP-1 cells. Interestingly, p38 MAPK activity diminished in the presence of anti-TNF- $\alpha$ antibody. These findings indicated that A. actinomycetemcomitans infection induces apoptosis in THP-1 cells and that p38 MAPK activity is directly involved in apoptosis. TNF- $\alpha$ may play an indirect role in apoptosis via enhanced p38 MAPK activity. A. actinomycetemcomitans-induced apoptosis of human immune cells may be important in terms of initiation and progression of periodontal diseases.
\end{abstract}

\section{INTRODUCTION}

Apoptosis is an important mechanism in mammalian development, homeostasis and immune response, and host-cell apoptosis may represent a host defence reaction (Walker et al., 1988; Cohen et al., 1992; Molloy et al., 1994). Monocytes/macrophages in host tissues serve as sentinels monitoring potential points of pathogenic insult, thus protecting deeper tissues from infection. In response to infection, monocytes/macrophages are known to secrete several cytokines, such as tumour necrosis factor alpha (TNF- $\alpha$ ). TNF- $\alpha$ may also induce apoptotic cell death, cellular proliferation, differentiation, inflammation and

Abbreviations: ERK, extracellular signal regulation kinase; JNK, c-Jun Nterminal kinase; LDH, lactate dehydrogenase; MAPK, mitogen-activated protein kinase; TNF- $\alpha$, tumour necrosis factor alpha. virus replication, in addition to induction of necrotic cell death (MacEwan, 2002). Several pathogenic bacteria, such as Shigella flexneri and Bordetella pertussis, participate in an essential pathogenic mechanism associated with promotion of inflammation and tissue damage via apoptosis of monocytes/macrophages. Furthermore, bacterial organisms promote the destruction of monocytic phagocytes by apoptosis, thus circumventing the first line of defence of the immune system (Mangan et al., 1993; Zychlinsky \& Sansonetti, 1997; Muro et al., 1999).

Recent studies have demonstrated that apoptosis regulation is modulated by multiple phosphorylation of several different protein kinases, including the major subtypes of the mitogen-activated protein kinase (MAPK) family: extracellular signal regulation kinase (ERK), c-Jun N-terminal kinase (JNK) and p38 MAPK. The MAPK family promotes cell 
survival and/or proliferation in response to growth-factor stimulation, or apoptosis in response to various stress stimuli. Several investigations have indicated that JNK and p38 MAPK activation processes are associated with apoptosis, whereas ERK activation is coupled with cell survival. The issue regarding whether MAPK activation determines cell survival or death remains controversial (Ip \& Davis, 1998; Kyriakis \& Avruch, 2001). MAPK signal cascades are activated in response to a variety of extracellular stimuli including osmotic shock, inflammatory cytokines such as TNF- $\alpha$, LPS, UV light and growth factors. However, the role of MAPK is not clear with respect to regulation of apoptosis following bacterial infection.

Actinobacillus actinomycetemcomitans, a Gram-negative, capnophilic, fermentative coccobacillus, has been implicated in the pathogenesis of several forms of periodontal disease. Recent studies have revealed that A. actinomycetemcomitans induces apoptosis in T cells (Shenker et al., 2001; Nalbant \& Zadeh, 2002). We have previously documented apoptosis in the murine macrophage cell line J774.1 and the human epithelial cell line $\mathrm{KB}$ following A. actinomycetemcomitans infection (Kato et al., 1995, 2000). However, the cellular and molecular mechanisms governing human immune-cell apoptosis as a result of A. actinomycetemcomitans infection remain unclear. The present investigation demonstrated that A. actinomycetemcomitans infection causes apoptosis in the human monocytic cell line THP-1. The potential involvement of MAPK cascades in this apoptosis was examined.

\section{METHODS}

Cells and growth conditions. A. actinomycetemcomitans strains $\mathrm{Y} 4$, 652 and $652^{\text {tttx }}$ were used in the present study. Leukotoxic activities of strains $\mathrm{Y} 4$ and 652 were reported as relatively low. Strain $652^{\text {tltx }}$, in which the leukotoxin gene ltxCABD from the leukotoxic strain JP2 has been inserted, was provided by Dr D. R. Demuth (University of Louisville, Louisville, KY, USA). Leukotoxic activity of $652^{\text {tltx }}$ was approximately three times higher than that of 652 (unpublished data). A. actinomycetemcomitans was grown in Todd-Hewitt broth (Difco Laboratories) supplemented with yeast extract $(1 \% \mathrm{w} / \mathrm{v})$ at $37^{\circ} \mathrm{C}$ for 1 day in an atmosphere of $5 \% \mathrm{CO}_{2}$ in air. Human monocytic THP-1 cells (JCRB0112.1; JCRB) were maintained in RPMI 1640 (Sigma) supplemented with $10 \%$ heat-inactivated fetal bovine serum (Sigma), penicillin $\left(100 \mathrm{U} \mathrm{ml}^{-1}\right)$ and streptomycin $\left(100 \mu \mathrm{g} \mathrm{ml} l^{-1}\right)$ at $37^{\circ} \mathrm{C}$ in $5 \% \mathrm{CO}_{2}$ in air.

In vitro infection. THP-1 cells were suspended in microtubes at a concentration of $2 \times 10^{6}$ cells $\mathrm{ml}^{-1}$. A. actinomycetemcomitans was harvested by centrifugation and suspended in RPMI 1640 without antibiotics. A. actinomycetemcomitans was added to THP-1 cells in microtubes; subsequently, tubes were centrifuged at $1000 \mathrm{~g}$ for $10 \mathrm{~min}$ at $4{ }^{\circ} \mathrm{C}$ and then incubated at $37^{\circ} \mathrm{C}$ for $30 \mathrm{~min}$. Infected THP- 1 cells were washed via a series of centrifugations with RPMI 1640 supplemented with penicillin, streptomycin and gentamicin $\left(200 \mu \mathrm{g} \mathrm{ml}^{-1}\right)$ to remove non-adherent bacteria. Following transfer to 24-well culture plates, infected cells were incubated for $24 \mathrm{~h}$ in the presence or absence of inhibitors: a p38 MAPK inhibitor (SB203580; Calbiochem-Novabiochem) or anti-human-TNF- $\alpha$ antibody (Sigma).

Determination of lactate dehydrogenase (LDH) release and DNA fragmentation. Infected THP-1 cells were incubated for $24 \mathrm{~h}$. LDH release by THP-1 cells was monitored with a commercial kit (Cytotoxicity Detection kit; Roche). LDH release was calculated using the following formula: $\mathrm{LDH}$ release $(\%)=100 \times\left(A_{490}\right.$ infected cells $-A_{490}$ uninfected cells $) / A_{490}$ uninfected cells treated with Triton X-100 (maximum LDH release).

DNA fragmentation was identified with a commercial ELISA kit as the quantitative determination of cytoplasmic histone-associated DNA fragments (Cell Death Detection ELISA PLUS; Roche). Specific enrichment of mono- and oligonucleosomes released into the cytoplasm was calculated using the following formula: enrichment factor $=A_{405}$ infected cells $/ A_{405}$ uninfected cells.

Internucleosomal DNA cleavage was examined by electrophoresis on a $2 \%$ agarose gel as follows. Infected cells were lysed with $10 \mathrm{mM}$ Tris/ $\mathrm{HCl}(\mathrm{pH} 7 \cdot 4)$ containing $5 \mathrm{mM}$ EDTA and $1 \%$ Triton X-100. Lysates were centrifuged to remove integral nuclei. Supernatants were digested with RNase $\left(0.5 \mathrm{mg} \mathrm{ml}^{-1}\right)$ for $1 \mathrm{~h}$ at $37^{\circ} \mathrm{C}$, incubated with proteinase $\mathrm{K}$ $\left(10 \mathrm{mg} \mathrm{ml}^{-1}\right)$ for $1 \mathrm{~h}$ at $50^{\circ} \mathrm{C}$ and extracted with phenol/chloroform $(1: 1, \mathrm{v} / \mathrm{v})$ prior to precipitation with ethanol. Precipitates were dried and then dissolved in $10 \mathrm{mM}$ Tris/ $\mathrm{HCl}$ ( $\mathrm{pH} \mathrm{8.0)} \mathrm{supplemented} \mathrm{with}$ $1 \mathrm{mM}$ EDTA. Electrophoresis was performed with $2 \%$ agarose gel, which was stained with ethidium bromide.

MAPK activity assay. Infected THP- 1 cells were incubated for $0,1,2,3$, $4,5,6$ or $24 \mathrm{~h}$. After incubation, cells were collected and lysed with $10 \mathrm{mM}$ Tris/HCl (pH 7.4) containing $100 \mathrm{mM} \mathrm{NaCl}, 1 \mathrm{mM}$ EDTA, $1 \mathrm{mM}$ EGTA, $1 \mathrm{mM} \mathrm{NaF}, 20 \mathrm{mM} \mathrm{Na}_{4} \mathrm{P}_{2} \mathrm{O}_{7}, 2 \mathrm{mM} \mathrm{Na}_{3} \mathrm{VO}_{4}, 1 \%$ Triton $\mathrm{X}-100,10 \%$ glycerol, $0 \cdot 1 \%$ SDS, $0 \cdot 5 \%$ deoxycholate, $1 \mathrm{mM}$ PMSF and a protease inhibitor cocktail (Sigma). Lysate samples were used for the MAPK activity ELISA assay. MAPK activity was measured on the basis of phosphorylated ERK1/2, p38 MAPK and JNK1/2, respectively [ERK1/2 (pTpY185/187) assay kit, p38 MAP kinase (pTpY180/182) assay kit and JNK1/2 (pTpY183/185) assay kit; BioSource International]. The MAPK activity of each sample, which was calculated from the standard curve included in each kit, was expressed as $\mathrm{U} \mathrm{ml}^{-1}$.

Quantitative analysis of TNF- $\boldsymbol{\alpha}$. Infected THP-1 cells were incubated for $12 \mathrm{~h}$. Culture supernatant was collected and assessed for TNF- $\alpha$ levels with a commercial ELISA kit (Human TNF- $\alpha$ ELISA kit; BioSource International).

Statistical analysis. An unpaired $t$-test was utilized for comparison of mean values between groups. Statistical significance was defined as $P<0 \cdot 05$.

\section{RESULTS}

\section{Cell death of THP-1 cells infected with $A$. actinomycetemcomitans}

LDH release by infected cells, which was bacterium: cell ratio-dependent, increased after A. actinomycetemcomitans infection. LDH release following infection with strains 652 and $652^{\text {tltx }}$ was slightly higher than with strain Y4. However, differences in LDH release between 652 and $652^{\text {tltx }}$ were not apparent (Fig. 1). DNA fragmentation (enrichment factor) of THP-1 cells infected with A. actinomycetemcomitans Y4 at bacterium: cell ratios of $500: 1,1000: 1$ and $2500: 1$ was $2 \cdot 18 \pm 0.04( \pm \mathrm{SD}), 2.99 \pm 0.01$ and $3.74 \pm 0.07$, respectively. Furthermore, a nucleosome ladder pattern of DNA degradation was observed in THP-1 cells infected with $A$. actinomycetemcomitans $\mathrm{Y} 4$, but not in uninfected cells (Fig. 2). 


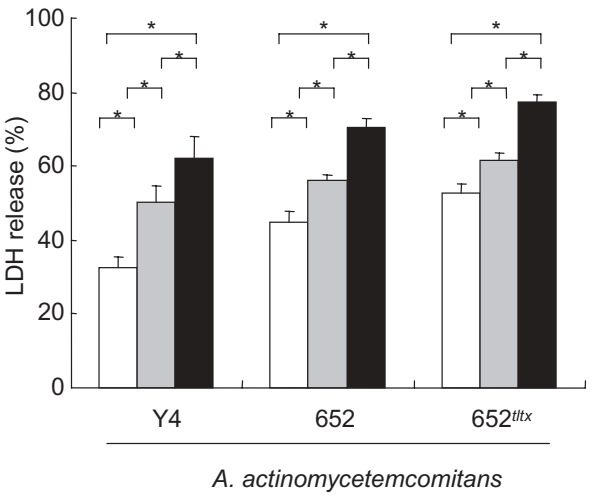

Fig. 1. Cell death of THP-1 cells induced by infection with various $A$. actinomycetemcomitans strains. THP-1 cells were infected with $A$. actinomycetemcomitans strains $Y 4,652$ and $652^{\text {tttx }}$ at bacterium : cell ratios of 500:1 (open bars), 1000:1 (shaded bars) and 2500:1 (filled bars). $\mathrm{LDH}$ release was measured at $24 \mathrm{~h}$ using a cytotoxicity detection kit. Asterisks indicate statistically significant differences $(P<0.05)$.
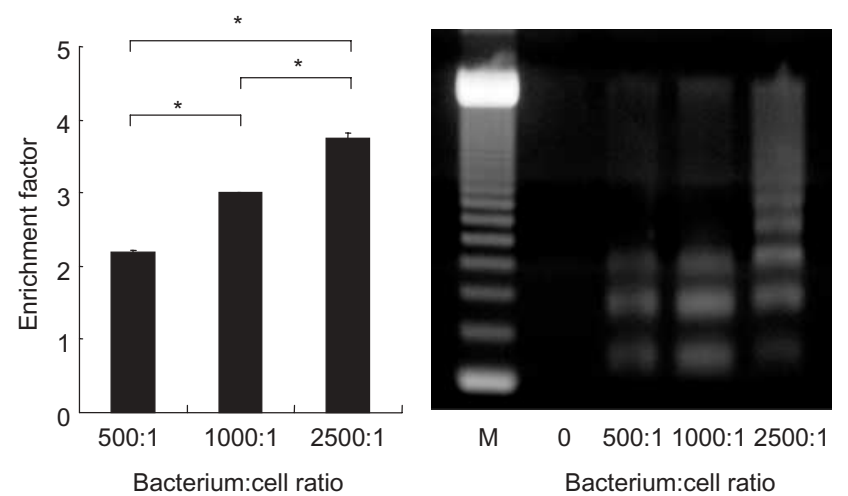

Fig. 2. DNA fragmentation of THP-1 cells infected with $A$. actinomycetemcomitans Y4. THP-1 cells were infected with $A$. actinomycetemcomitans $Y 4$ at bacterium : cell ratios of 0 (uninfected), $500: 1$, $1000: 1$ and $2500: 1$ for $24 \mathrm{~h}$. The enrichment factor was determined using the Cell Death Detection ELISA PLUS kit. Asterisks indicate statistically significant differences $(P<0.05)$. Internucleosomal DNA cleavage was determined by electrophoresis on a $2 \%$ agarose gel. Cellular material was isolated from THP-1 cells at $24 \mathrm{~h}$ after infection with $A$. actinomycetemcomitans $Y 4$. Lane M, 123 bp DNA ladder.

\section{Roles of MAPK and TNF- $\alpha$ in apoptosis of THP-1 cells infected with $A$. actinomycetemcomitans}

The MAPK activity of infected THP-1 cells was measured using a commercial ELISA kit. Phosphorylated p38 MAPK activity was elevated significantly in infected cells relative to uninfected cells. Activity attained peak levels at $1 \mathrm{~h}$ after infection. ERK1/2 and JNK1/2 activities displayed only small changes in comparison with p38 MAPK activity (Fig. 3). Therefore, the role of p38 MAPK in apoptosis was examined.

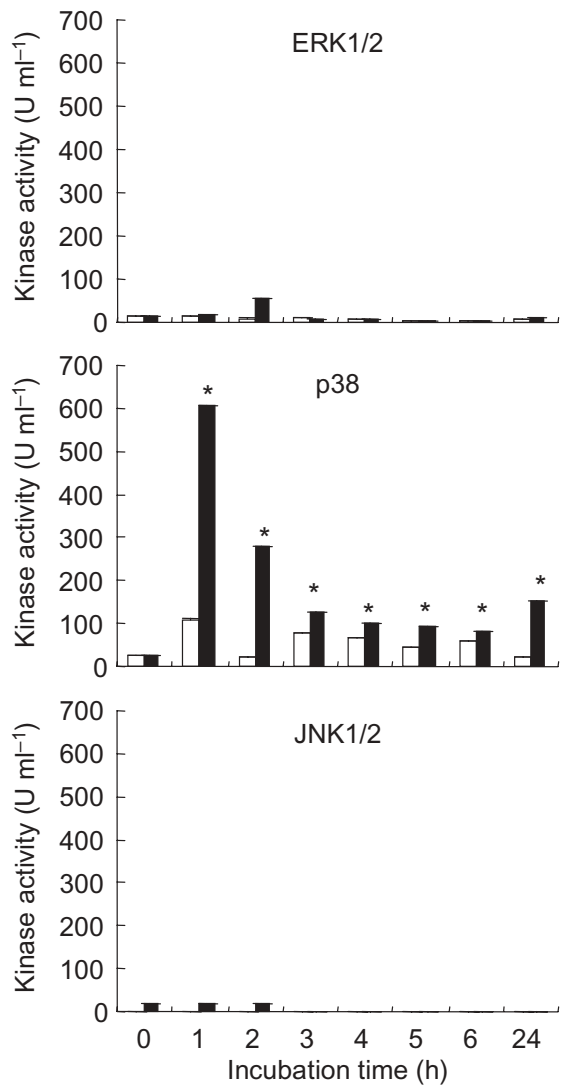

Fig. 3. MAPK activity of $A$. actinomycetemcomitans-infected THP-1 cells. ERK1/2, p38 MAPK and JNK1/2 activity in A. actinomycetemcomitans-infected THP-1 cells was examined by ELISA. THP-1 cells were infected with $A$. actinomycetemcomitans $Y 4$ at bacterium : cell ratios of 0 (uninfected; open bars) and 1000: 1 (filled bars). Asterisks indicate statistically significant differences based on comparison of uninfected and infected cells $(P<0.05)$.

LDH release and DNA fragmentation declined significantly in infected THP-1 cells in a dose-dependent manner following introduction of the p38 MAPK inhibitor SB203580 (Fig. 4). Moreover, the nucleosome ladder pattern detected in agarose gels disappeared following the addition of SB203580; this phenomenon was dose-dependent. The level of TNF- $\alpha$ was $30 \mathrm{pg} \mathrm{ml}^{-1}$ in uninfected cells at $12 \mathrm{~h}$ after infection; in contrast, the level was approximately $2000 \mathrm{pg} \mathrm{ml}^{-1}$ in infected cells. TNF- $\alpha$ levels and p38 MAPK activity decreased markedly in infected cells following the addition of SB203580 (Fig. 5).

In the presence of $20 \mu \mathrm{g}$ anti-TNF- $\alpha$ antibody $\mathrm{ml}^{-1}$, LDH release and DNA fragmentation decreased in infected THP-1 cells (Fig. 6). In addition, TNF- $\alpha$ levels and p38 MAPK activity were reduced significantly in the presence of $20 \mu \mathrm{g}$ anti-TNF- $\alpha$ antibody $\mathrm{ml}^{-1}$ (Fig. 7). However, LDH release in uninfected cells incubated with $2000 \mathrm{pg}$ human TNF- $\alpha \mathrm{ml}^{-1}$ for $12 \mathrm{~h}$ was only $10 \%$ (data not shown). 

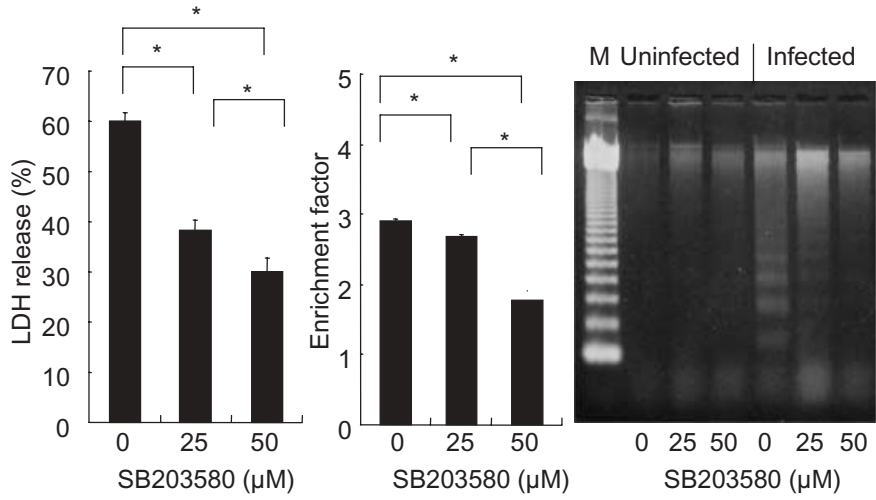

Fig. 4. Effect of SB203580 on cell death of THP-1 cells. THP-1 cells were infected with $A$. actinomycetemcomitans $\mathrm{Y} 4$ at bacterium: cell ratios of 0 (uninfected) and 1000:1 (infected). $\mathrm{LDH}$ release and enrichment factor were determined in the presence or absence of SB203580 $(0,25$ and $50 \mu \mathrm{M}$; results for uninfected cells not shown). Asterisks indicate statistically significant differences $(P<0.05)$. Internucleosomal DNA cleavage was determined by electrophoresis on $2 \%$ agarose gels. Lane M, 123 bp DNA ladder.
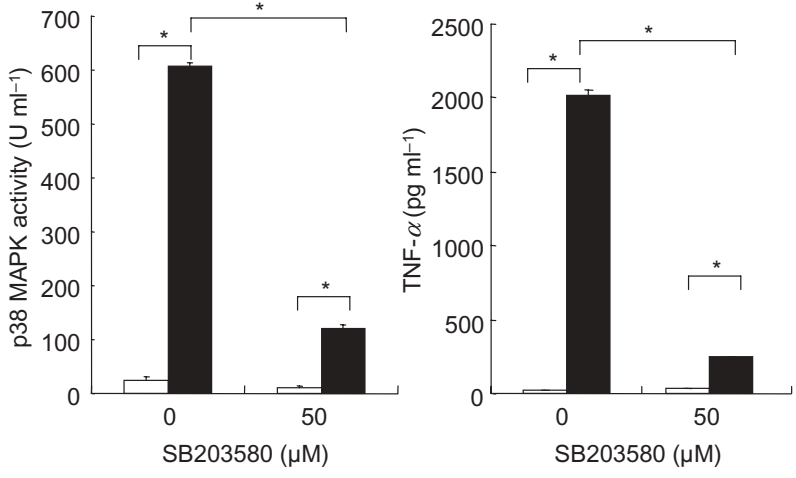

Fig. 5. Effect of SB203580 on p38 MAPK activity and TNF- $\alpha$ production in THP-1 cells. THP-1 cells were infected with $A$. actinomycetemcomitans $Y 4$ at bacterium : cell ratios of $O$ (uninfected; open bars) and 1000:1 (filled bars). p38 MAPK activity and TNF- $\alpha$ levels were measured in the presence or absence of SB203580 (0, 25 and $50 \mu \mathrm{M}$ ). Asterisks indicate statistically significant differences $(P<0.05)$
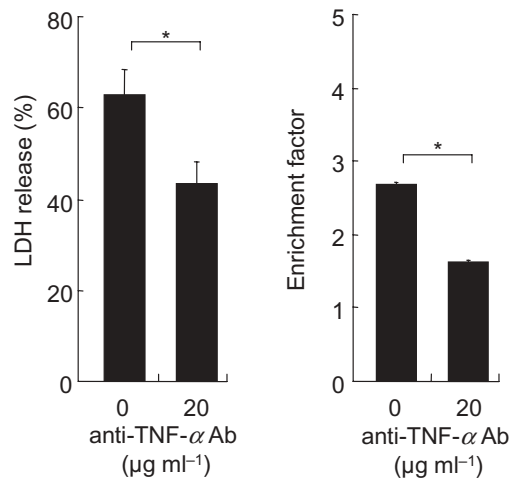

Fig. 6. Effects of anti-TNF- $\alpha$ antibody on cell death of THP-1 cells. THP- 1 cells were infected with $A$. actinomycetemcomitans $Y 4$ at bacterium : cell ratios of 0 (uninfected) and $1000: 1$. LDH release and enrichment factor were determined in the presence or absence of anti-TNF- $\alpha$ antibody ( $20 \mu \mathrm{g} \mathrm{ml}^{-1}$ ) (results for uninfected cells not shown). Asterisks indicate statistically significant differences $(P<0.05)$
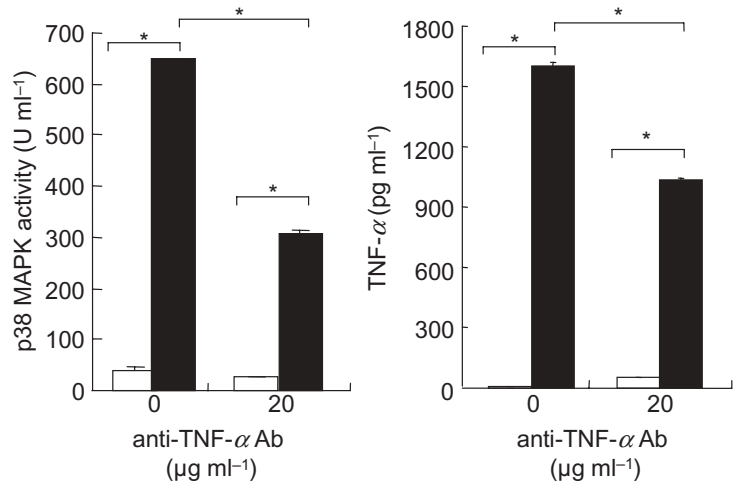

Fig. 7. Effect of anti-TNF- $\alpha$ antibody on p38 MAPK activity and TNF$\alpha$ production of THP-1 cells. THP-1 cells were infected with $A$. actinomycetemcomitans $Y 4$ at bacterium : cell ratios of 0 (uninfected; open bars) and 1000:1 (filled bars). p38 MAPK activity and TNF- $\alpha$ levels were measured in the presence or absence of anti-TNF- $\alpha$ antibody $\left(20 \mu \mathrm{g} \mathrm{ml}^{-1}\right)$. Asterisks indicate statistically significant differences $(P<0.05)$.

\section{DISCUSSION}

Monocytes/macrophages play a central role in inflammatory reactions caused by pathogenic bacteria. Many pathogens have evolved specific mechanisms for avoiding, altering or disabling the antimicrobial effects of monocytes/macrophages. We have previously reported that $A$. actinomycetemcomitans infection induced apoptotic cell death of the murine macrophage cell line J774.1 (Muro et al., 1997; Nonaka et al., 1998, 2001; Nakashima et al., 2002). The present study demonstrated the death of human monocytic THP-1 cells following A. actinomycetemcomitans infection (Fig. 1). Rapid killing of neutrophils and monocytes by $A$. actinomycetemcomitans within minutes to a few hours has been documented previously (Mangan et al., 1991).

One of the potential virulence factors produced by $A$. actinomycetemcomitans is a leukotoxin, which generates membrane pores and kills several lymphoid cell types. Cells exposed to low concentrations of leukotoxin exhibit altera- 
tions consistent with apoptosis (Korostoff et al., 1998; Fukunaga \& Tsuruda, 2001). Therefore, three strains of $A$. actinomycetemcomitans, Y4, 652 and leukotoxin geneinserted $652\left(652^{\mathrm{tttx}}\right)$, were employed in this investigation. These strains exerted similar cytotoxic effects on THP-1 cells (Fig. 1), indicating that leukotoxin alone cannot adequately explain A. actinomycetemcomitans cytotoxicity in the present study.

Cytoplasmic histone-associated DNA fragmentation increased; moreover, the typical ladder pattern was observed on an agarose gel following A. actinomycetemcomitans Y4 infection (Fig. 2). These findings suggested that cell death of THP-1 cells following A. actinomycetemcomitans Y4 infection occurs via apoptosis.

Several investigators have reported that p38 MAPK activity may be involved in the regulation of apoptosis and that inhibition of p38 MAPK activity can suppress apoptosis (Buscher et al., 1988; Kyriakis et al., 1994; Oses-Prieto et al., 2000). Salmonella infection led to MAPK activation in macrophages shortly after infection (Procyk et al., 1999). MAPK controls a wide variety of cellular processes, including mitogenesis and the cellular stress response. Hobbie et al. (1997) noted that activation of MAPK signalling cascades by Salmonella LPS leads to phosphorylation. We demonstrated that p38 MAPK activity was elevated as a result of $A$. actinomycetemcomitans infection; furthermore, the highest activity peak was evident $1 \mathrm{~h}$ after infection (Fig. 3 ).

LDH release and DNA fragmentation decreased in infected cells following the introduction of an inhibitor of p38 MAPK; moreover, no apparent increase in the proportion of fragmented DNA, as observed on an agarose gel, was detected (Fig. 4). These results suggested the involvement of $\mathrm{p} 38$ MAPK activity in the apoptotic cell death of THP-1 cells infected with A. actinomycetemcomitans. MAPK cascades are activated mainly by a range of stress stimuli, including cytokines such as IL1 and TNF- $\alpha$; furthermore, MAPK has been shown to play a pivotal role in TNF signalling (MacEwan, 2002). The present study revealed that inhibition of p38 MAPK activity led to a decrease in TNF- $\alpha$ production (Fig. 5). Nagahira et al. (2001) demonstrated that SB203580 inhibited LPS-induced production of TNF- $\alpha$ protein and expression of mRNA in human monocytes/macrophages. Additionally, p38 MAPK may participate in the transcription and stabilization of TNF- $\alpha$ mRNA expression in LPS-treated monocytes/macrophages (Dean et al., 1999).

TNF- $\alpha$ functions in the regulation of life and death processes in many cell types. The present investigation demonstrated that LDH release, DNA fragmentation and TNF- $\alpha$ levels were reduced in infected cells as a result of the presence of antiTNF- $\alpha$ antibody (Figs 6 and 7). Interestingly, p38 MAPK activity was also diminished (Fig. 7). However, exogenous TNF- $\alpha$ could not induce apoptosis in uninfected THP-1 cells. These results suggested that TNF- $\alpha$ is involved indirectly in apoptosis via increased p38 MAPK activity.

In conclusion, these findings indicate that $A$. actinomyce- temcomitans infection induces apoptosis in THP-1 cells and that the p38 MAPK pathway is involved in this apoptosis. Furthermore, TNF- $\alpha$ released by infected THP-1 cells resulted in elevated p38 MAPK activity. Activation or prevention of cell death could be a critical factor in terms of the outcome of an infection. Repeated immune-cell apoptosis occurs in periodontal tissue during chronic infection with A. actinomycetemcomitans, which may potentially lead to periodontal tissue destruction. Elucidation of the cellular and molecular mechanisms of A. actinomycetemcomitans-infected monocyte/macrophage apoptosis will enhance our understanding of the pathogenesis of $A$. actinomycetemcomitans infection, which will facilitate identification of specific molecular targets for therapy of periodontal diseases.

\section{ACKNOWLEDGEMENTS}

We wish to thank Dr Demuth for providing A. actinomycetemcomitans $652^{\text {tltx }}$. This work was supported by a grant-in-aid for scientific research (nos 13771310 and 15791246) from the Ministry of Education, Science Research and Culture of Japan.

\section{REFERENCES}

Buscher, M., Rahmsdorf, H. J., Litfin, M., Karin, M. \& Herrlich, P. (1988). Activation of the c-fos gene by UV and phorbol ester: different signal transduction pathways converge to the same enhancer element. Oncogene 3, 301-311.

Cohen, J. J., Duke, R. C., Fadok, V. A. \& Sellins, K. S. (1992). Apoptosis and programmed cell death in immunity. Annu Rev Immunol 10, 267-293.

Dean, J. L., Brook, M., Clark, A. R. \& Saklatvala, J. (1999). p38 mitogenactivated protein kinase regulates cyclooxygenase-2 mRNA stability and transcription in lipopolysaccharide-treated human monocytes. J Biol Chem 274, 264-269.

Fukunaga, M. \& Tsuruda, K. (2001). Actinobacillus actinomycetemcomitans induces lethal effects on the macrophage-like human cell line U937. Oral Microbiol Immunol 16, 284-289.

Hobbie, S., Chen, L. M., Davis, R. J. \& Galan, J. E. (1997). Involvement of mitogen-activated protein kinase pathways in the nuclear responses and cytokine production induced by Salmonella typhimurium in cultured intestinal epithelial cells. J Immunol 159, 5550-5559.

Ip, Y. T. \& Davis, R. J. (1998). Signal transduction by the c-Jun Nterminal kinase (JNK) - from inflammation to development. Curr Opin Cell Biol 10, 205-219.

Kato, S., Muro, M., Akifusa, S., Hanada, N., Semba, I., Fujii, T., Kowashi, Y. \& Nishihara, T. (1995). Evidence for apoptosis of murine macrophages by Actinobacillus actinomycetemcomitans infection. Infect Immun 63, 3914-3919.

Kato, S., Nakashima, K., Inoue, M., Tomioka, J., Nonaka, K., Nishihara, T. \& Kowashi, Y. (2000). Human epithelial cell death caused by Actinobacillus actinomycetemcomitans infection. J Med Microbiol 49, 739-745.

Korostoff, J., Wang, J. F., Kieba, I., Miller, M., Shenker, B. J. \& Lally, E. T. (1998). Actinobacillus actinomycetemcomitans leukotoxin induces apoptosis in HL-60 cells. Infect Immun 66, 4474-4483.

Kyriakis, J. M. \& Avruch, J. (2001). Mammalian mitogen-activated protein kinase signal transduction pathways activated by stress and inflammation. Physiol Rev 81, 807-869. 
Kyriakis, J. M., Banerjee, P., Nikolakaki, E., Dai, T., Rubie, E. A., Ahmad, M. F., Avruch, J. \& Woodgett, J. R. (1994). The stress-activated protein kinase subfamily of c-Jun kinases. Nature 369, 156-160.

MacEwan, D. J. (2002). TNF ligands and receptors - a matter of life and death. Br J Pharmacol 135, 855-875.

Mangan, D. F., Taichman, N. S., Lally, E. T. \& Wahl, S. M. (1991). Lethal effects of Actinobacillus actinomycetemcomitans leukotoxin on human T lymphocytes. Infect Immun 59, 3267-3272.

Mangan, D. F., Mergenhagen, S. E. \& Wahl, S. M. (1993). Apoptosis in human monocytes: possible role in chronic inflammatory diseases. J Periodontol 64, 461-466.

Molloy, A., Laochumroonvorapong, P. \& Kaplan, G. (1994). Apoptosis, but not necrosis, of infected monocytes is coupled with killing of intracellular bacillus Calmette-Guerin. J Exp Med 180, 1499-1509.

Muro, M., Koseki, T., Akifusa, S., Kato, S., Kowashi, Y., Ohsaki, Y., Yamato, K., Nishijima, M. \& Nishihara, T. (1997). Role of CD14 molecules in internalization of Actinobacillus actinomycetemcomitans by macrophages and subsequent induction of apoptosis. Infect Immun 65, 1147-1151.

Muro, M., Nakashima, K., Tomioka, J., Kato, S., Nonaka, K., Yoshida, T., Inoue, M., Nishihara, T. \& Kowashi, Y. (1999). Inhibitory effect of lipopolysaccharide on apoptotic cell death in macrophages infected with Actinobacillus actinomycetemcomitans. FEMS Microbiol Lett 175, 211-216.

Nagahira, A., Nagahira, K., Murafuji, H., Abe, K., Magota, K., Matsui, M. \& Oikawa, S. (2001). Identification of a novel inhibitor of LPS-induced TNF- $\alpha$ production with antiproliferative activity in monocyte/macrophages. Biochem Biophys Res Commun 281, 1030-1036.

Nakashima, K., Tomioka, J., Kato, S., Nishihara, T. \& Kowashi, Y. (2002). Nitric oxide-mediated protection of A. actinomycetemcomitansinfected murine macrophages against apoptosis. Nitric Oxide 6, 61-68.
Nalbant, A. \& Zadeh, H. H. (2002). Actinobacillus actinomycetemcomitans induces apoptosis of $\mathrm{T}$ lymphocytes by the Fas and Fas ligand pathway. Oral Microbiol Immunol 17, 277-284.

Nonaka, K., Ishisaki, A., Muro, M., Kato, S., Oido, M., Nakashima, K., Kowashi, Y. \& Nishihara, T. (1998). Possible involvement of protein kinase $\mathrm{C}$ in apoptotic cell death of macrophages infected with Actinobacillus actinomycetemcomitans. FEMS Microbiol Lett 159, $247-254$

Nonaka, K., Ishisaki, A., Okahashi, N., Koseki, T., Kato, S., Muro, M., Nakashima, K., Nishihara, T. \& Kowashi, Y. (2001). Involvement of caspases in apoptotic cell death of murine macrophages infected with Actinobacillus actinomycetemcomitans. J Periodontal Res 36, 40-47.

Oses-Prieto, J. A., Lopez-Moratalla, N., Santiago, E., Jaffrezou, J. P. \& Lopez-Zabalza, M. J. (2000). Molecular mechanisms of apoptosis induced by an immunomodulating peptide on human monocytes. Arch Biochem Biophys 379, 353-362.

Procyk, K. J., Kovarik, P., von Gabain, A. \& Baccarini, M. (1999). Salmonella typhimurium and lipopolysaccharide stimulate extracellularly regulated kinase activation in macrophages by a mechanism involving phosphatidylinositol 3-kinase and phospholipase D as novel intermediates. Infect Immun 67, 1011-1017.

Shenker, B. J., Hoffmaster, R. H., Zekavat, A., Yamaguchi, N., Lally, E. T. \& Demuth, D. R. (2001). Induction of apoptosis in human T cells by Actinobacillus actinomycetemcomitans cytolethal distending toxin is a consequence of $\mathrm{G}_{2}$ arrest of the cell cycle. J Immunol 167, 435-441.

Walker, N. I., Harmon, B. V., Gobe, G. C. \& Kerr, J. F. (1988). Patterns of cell death. Methods Achiev Exp Pathol 13, 18-54.

Zychlinsky, A. \& Sansonetti, P. (1997). Perspectives series: host/ pathogen interactions. Apoptosis in bacterial pathogenesis. J Clin Invest 100, 493-495. 